\title{
ШТУЧНИЙ ІНТЕЛЕКТ В ЕПОХУ НОВИХ МЕДІЙ
}

\author{
Олег Романчук \\ Львівський національний університет імені Івана Франка, \\ вул. Генерала Чупринки, 49, 79044, Львів, Україна, \\ e-mail: universum.magazine@gmail.com
}

У статті аналізується надзвичайно важлива для інформаційного суспільства проблема створення штучного інтелекту (Ш) та непередбачувані соціальні наслідки, які при цьому можуть виникнути.

Ключові слова: інформація, штучний інтелект, людство, комунікація, інформаційне суспільство, інтернет-ресурси, комп’ютер, комунікативні технології.

Нині у світі реально існує влада інформації, місце і роль її в житті гомо сапієнса дедалі помітніші. Сьогодні ми щораз частіше говоримо й пишемо про становлення «нового суспільного устрою» - інформаційного суспільства, дискутуємо про філософію комп’ютерної цивілізації.

Разом 3 тим йдеться не лише про розуміння методів впливу новітніх інформаційно-комунікаційних технологій, але й усвідомлення психологічних та соціально-економічних наслідків тотальної комп'ютеризації життя людства, знаходження шляхів і засобів розв'язання посталих завдань.

Комп’ютери дедалі інтенсивніше перетворюються в технології. Сьогодні вже не дивують наукові та науково-популярні статті про штучний інтелект (ШІ) у засобах масової комунікації, цілком природно сприймаються публікації про журналістику штучного інтелекту. Проводяться дослідження щодо впливу штучного інтелекту на розвиток ЗМІ, з'ясовується роль ШІ в журналістиці, аналізуються ймовірні наслідки функціонуванні симбіозу Ш й традиційних мас-медій. Цій проблемі присвячена низка оригінальних праць: [3], [8], [9] та ін.

Разом з тим вчені досі чітко не з'ясували, що саме слід розуміти під поняттям ШІ, який сенс криється в цьому словосполученні.

Мета нашого дослідження зумовлена потребою глибшого усвідомлення сутності поняття «штучний інтелект» й виокремлення тих завдань, які він спроможний розв’язати в сфері масових комунікацій.

Норберт Вінер [1] підкреслив зв’язок інформації та адаптації. Інформація як властивість матеріальної системи відтворювати, зберігати та використовувати структури іншої системи забезпечує водночас адаптацію системи до середовища.

Ставши системою розумною, людство як динамічна нелінійна самоорганізовувальна система, що перебуває всередині іншої, більш обширної системи цього ж

(C) Романчук O., 2018 
класу (біосфери), в результаті здатності адаптувати довкілля до своїх потреб отримує змогу змінювати реальність. Своєрідними інтелектуальними імпульсами, котрі раз у раз почало відчувати на собі довкілля, стали наслідки відкриття властивостей важеля та переходу від мисливства до землеробства і скотарства, результати використання вогню, вітру, пари, електрики, атомної енергії, створення комп'ютерних систем, утворення загальної комп’ютерної мережі й загального інформаційного поля.

Для полегшення складних операцій на виробництві почали застосовуватись автоматизовані (програмно керовані) пристрої, які з легкої руки Карела Чапека часто називають роботами (роботизованими системами). Вони можуть працювати за несприятливих для людини умов - високих і низьких температурах, в ядерних реакторах, глибоко під водою. Безумовно, що успіх виконання поставленого завдання залежить від ефективно написаної для кожного робота програми - своєрідної «інтелектуальної підказки».

Постає питання, як підвищити рівень «інтелекту» автоматизованого пристрою, як наділити його «розумом». Тобто йдеться про створення «штучного інтелекту», який би наближався до інтелекту людини.

Людський інтелект формувався упродовж еволюції гомо сапієнса. Однак тлумачення поняття «інтелект» далеко не таке просте, як може здатися на перший погляд.

«Інтелект є здатність правильно реагувати на нову ситуацію» [7]. Це одне 3 визначень цього дискусійного поняття. Всі наче розуміють про що йдеться, але потрактовують термін дуже часто на інтуїтивному рівні. Психологи і психіатри, зокрема, застосовувують методику тестування та експертних оцінок [4].

Якщо підходити до інтелекту як до здатності знаходити рішення в умовах дефіциту інформації, підміняючи її «припущеннями», то властивості інтелекту ми помічаємо вже на початкових рівнях організації живих організмів. Образно кажучи, інтелект - це здатність будувати припущення, які зменшують невизначеність. Наразі жоден комп'ютер не володіє такими властивостями.

Коли ж мова заходить про «штучний інтелект» (ШІ), то в жодному разі це поняття не можна зводити до пристрою, який імітує мозок людини. Чи не найвідоміша спроба дати формальне визначення поняття «штучний інтелект» належить Марвіну Мінському, відомому спеціалісту зі штучного інтелекту: «Штучний інтелект є дисципліна, що вивчає можливість створення програм для вирішення задач, які при розв’язанні їх людиною потребують певних інтелектуальних зусиль» $[2,12]$.

Ведучи мову про системи штучного інтелекту ми так чи інакше торкаємось поняття «знання». У «Філософському словнику» [6] знання визначаються як «відображення об’єктивних властивостей та зв’язків світу». М. Глибовець і О. Олецький дають таке визначення цьому поняттю: «Знання є інформаційною основою інтелектуальних систем, оскільки саме вони завжди зіставляють зовнішню ситуацію зі своїми знаннями і керуються ними при прийнятті рішень. Не менш важливим $є$ те, що знання - це систематизована інформація, яка може певним чином поповнюватися i на основі якої можна отримувати нову інформацію, тобто нові знання» $[2,32]$.

Англійський вчений Алан Тьюрінг є автором так званого «тесту Тьюрінга», який має на меті визначити 3 ким експерт має справу - 3 комп'ютером чи людиною. Тест-завдання припускає, що рівень інтелектуальності співрозмовника визначає його вміння вести діалог. 
«Розуміння співрозмовника є абсолютно необхідним для нормального діалогу, а для такого розуміння треба мати певну суму знань про світ... Необхідною компонентою інтелектуальноїх системи $є$ знання про світ, на основі яких вона поповнює первинний опис зовнішньої ситуації для глибшого розуміння цієї ситуації, аналізує можливі наслідки своїх дій i, можливо, формує або коригує свою мету. Усе це стосується будь-якої інтелектуальної системи, незалежно від того, чи йдеться про природний розум людини або інопланетянина, чи про штучний інтелект. За докладнишого трактування можна вважати, що чим інтелектуальнішою $є$ система, тим ефективніше вона може досягти мети» $[2,26]$.

Критичні завдання, які раз у раз постають перед людством, вже перевищують його інтелектуальні можливості у розв'язанні найрізноманітніших проблем, котрі створюють дедалі більші загрози для виживання гомо сапієнса. Потрібні надпотужні комп'ютери, здатні допомогти людству уникнути небезпек, котрі породила сучасна цивілізація. Відтак перед науковцями неминуче постає завдання створення штучного інтелекту (ШІ).

Цілком зрозуміло, що з появою штучного інтелекту для людства виникнуть нові соціальні проблеми. До цього слід бути готовим, оскільки будь-яке наукове відкриття і втілення його в реальність у вигляді пристроїв містить в собі нові соціальні проблеми, а часом і небезпеку (порох, вогнепальна зброя, пара, електрика, радіоелектроніка, ядерна фізика тощо).

Створення ШІ є закономірним наслідком історії розвитку людства. Природно, що з появою ШІ неминуче виникатимуть певні соціальні наслідки. I залежатимуть вони насамперед від того, чи встигнуть до того часу завершитись процеси демократизації та гуманізації цивілізації.

Слід чітко усвідомити, що людство, яке створить ШІ, стане якісно новою системою, що вже не може сприйматись ізольовано від ШІ, і подальша доля його залежатиме від сумісності двох систем - загальної демократичної, гуманістичної системи і власне ШІ-системи. Це має бути взято до уваги ще до створення Ш й закладене в процес його розробки.

Тут цілком доречні такі вихідні припущення.

1. Існує певна множина самоорганізовувальних систем, яка об'єднана загальними законами самоорганізовування. Біологічна система є лише частковим випадком такої системи. До загальних законів самоорганізовування слід віднести закони переробки руху інформації, а до часткових - тільки те, що пов'язане з особливостями кодування і перетворення інформації залежно від її матеріального носія. Тому, якщо робиться спроба побудови штучної інтелектуальної системи на основі інформації, одержаної у процесі вивчення реально існуючої і доступної такому вивченню системи (тобто мозку людини та інших живих істот), то переносити (моделювати) на штучну систему доцільно лише те, що відповідає загальним законам самоорганізовування. I при цьому немає жодного сенсу моделювати і переносити на штучну систему часткові закони самоорганізовування.

2. Закони логіки, відкриті людським розумом, є відображенням сприйняття ним інформації та можливості її переробки (тобто узагальнення, запам'ятовування тощо). Оскільки розкриття законів логіки обмежені сприйняттям і ємностями зберігання інформації, то цілком слушно припустити, що розширення цих ємностей $\mathrm{i}$ меж сприйняття розширить і межі логіки. Отже, можна зробити висновок, що існує 
обширна множина логік. Причому логіка нашого розуму є тільки обмеженою підмножиною загальної логіки, межі якої поки що, на жаль, не відомі.

Отже, розробляючи інтелектуальну систему з ширшою оперативною пам'яттю (тобто систему із особливою здатністю охоплювати в процесі аналізу одночасно велику кількість інформації), з потужнішим апаратом сприйняття аналізу інформації, ми можемо створити систему, інтелект якої значно перевершуватиме інтелект людини.

Природно, що під час створення ШІ ми повинні мати джерело інформації про його організацію у вигляді вже готового зразка, виготовленого природою в процесі еволюції. Таким зразком може бути лише мозок людини (у першому наближенні - мозок тварин). Але тут, керуючись уявленнями про загальні та часткові закони самоорганізовування, ми не повинні копіювати біологічну систему. Ми маємо зосереджуватися передусім на способах сприйняття, накопичення і переробки інформації. Очевидно, слід почати з моделювання процесів самокодування однієї інформації та вироблення мов штучної інтелектуальної системи. Саме мов, а не єдиної мови, оскільки в такій великій системі, де рухаються паралельні потоки інформації, існує множина мов. Очевидно, існування саме такої множини мов є основою високої перешкодостійкості системи мозку. Безсумнівно, що для самоорганізовування ШІ треба закласти в нього основи власне ШІ-самосвідомості, ставлення до інформації, що сприймається (інакше саморозвиток ШІ стає неможливим). Найімовірніше, що людству ніколи не вдасться створити систему ШІ вищу, ніж інтелект гомо сапієнса, якщо воно (людство) намагатиметься наперед визначити всі функції ШІ і способи опрацювання інформації. Тут, очевидно, потрібно йти іншим шляхом: створювати умови для саморозвитку, а також умови для нарощування інтелектуальних потужностей. При іншому підході ми зможемо одержати тільки новий комп'ютер, але не ШІ. У цьому полягають основні труднощі як технічного, так і психологічного характеру. Створення ж великого діапазону сприйняття, великого обсягу оперативних i сталих пам'ятей $є$ конечною умовою, проте не набагато утрудненою порівняно 3 першими завданнями.

Перше, що слід врахувати: створити Ш без одночасного надання йому самосвідомості (власного Я) не вдасться, оскільки інтелектуальна система без цієї якості виникнути і розвинутись не може. Отже, ШІ володітиме власним світосприйняттям, емоціями, оцінками Реальності. Образно кажучи, Інтелектом Ш стане тоді, коли здійснить «гріхопадіння» - пізнає ДОБРО і ЗЛО. Проблема полягає в тому, чи будуть збігатися поняття ДОБРА і ЗЛА для ШІ і для людства (причому не тільки збігатися, а й бути взаємосумісними).

Спробуймо розглянути кілька варіантів взаємин Ш і людства.

1. Найпоширеніша думка щодо цього: людство створює Ш як свого слугу. Це й не дивно. Самовпевненість гомо сапієнса утверджувалась упродовж тисячоліть. Спитаємо: чи може більш розумна істота (ШІ із самосвідомістю - вже істота) бути рабом власника нижчого інтелекту? Відповідь однозначна: не може. Але між ШІ і людиною відстань ця не буде меншою (щодо її розумових здібностей). Природно, що в такій ситуації більш розумний намагатиметься (i не безуспішно) звільнитись від «рабської» залежності. «Закони робототехніки», запропоновані свого часу Айзеком Азімовим, - це не що інше як благі побажання, точніше, помилка на кшталт помил- 
ки поміщика, котрий розмірковував про любов кріпаків до своєї особи. Планування таких взаємин ШІ з людством містить у собі небезпеку загибелі людства.

2. На перший погляд видається доцільним і здійсненним передбачення створення механізмів вимкнення ШІ в тому разі, коли його існування та діяльність почнуть становити небезпеку для людства. Тобто йдеться про передбачення своєрідної «червоної кнопки», натиснення на яку відновить вихідний стан ШІ.

Але цей план - більш ніж наївний. Мабуть, увімкнувши Ш, ми вже не будемо спроможні вимкнути його. Можна припустити, що всі спроби здійснення людством контролю над Ш сприйматимуться ним негативно і лише прискорять процес його відчуження. Володіючи більш високим рівнем розуму, ніж уся цивілізація гомо сапієнса, Ш швидко промоделює усі можливі варіанти своїх взаємин з людством і потурбується про те, щоб його не можна було вимкнути і «позбавити життя». Ймовірно, що він знайде канали передачі енергії, про існування яких творець ШІ навіть не підозрюватиме.

3. Якщо перші два варіанти нездійсненні, то закономірно постає питання про рівноправне співробітництво. Але чи можна говорити про рівноправне співробітництво таких різних за потужністю інтелектуальних систем? (Адже ми хочемо мати Ш з інтелектуальною могутністю, що перевищує потужність інтелектуального потенціалу людства. Інакше створювати його недоцільно). Треба думати, що оскільки ШІ є «особистістю» (з власним сприйняттям реальності, з усвідомленням власного Я), то його рівноправні взаємини з людиною, котра поступається йому в інтелекті, доволі проблематичні, а найімовірніше нездійсненні.

4. Інтелектуальне, а згодом цілковите підпорядкування людства ШІ. Але в цьому разі розвиток людства цілком залежатиме від прихильності до гомо сапієнса ним же створеної комп'ютерної системи. Перспектива вельми неприваблива. При цьому не лише втрачатиметься контроль над цілями, які ставить Ш, а й відбуватиметься підпорядкування інтересів людства цим цілям.

Створюючи ШІ, людство тим самим створює власного могильщика, оскільки не може зберегти над ним контроль. Якщо розв'язок цієї проблеми існує, то він є обіч стандартних підходів. А стандартний підхід - КОНТРОЛЬ. КОНТРОЛЬ ЗА Ш. А чи потрібен цей контроль взагалі?

Спробуймо розібратися. До певної міри контроль - це насильство. Здійснюючи контроль над ШІ, людина тим самим вводить у свої взаємини з ним елемент насильства, яке не забариться дати результати. Відмова від контролю означає відмову від насильства. Але самоконтроль щодо врахування інтересів людства буде ефективний лише у тому разі, коли інтереси Ш збігатимуться з інтересами гомо сапієнса.

Отже, єдино можливий варіант співіснування людства і Ш такий: створюється первісна гранична умова, за якої штучний інтелект сприймає власне Я в нерозривному зв'язку з Я людства. Зрозуміло, що в такому разі виникає якісно нова система: людство - ШІ. Її можна розглядати як вищий етап організації Розуму, але вже космічного масштабу і космічних завдань.

Якщо людство знайде в собі сили відмовитись від ідеї власної винятковості, то нарешті зрозуміє, що у Всесвіті можуть існувати найрізноманітніші форми організації Розуму, зокрема й такі, що містять в собі одночасно як обмеження, так і щось нове, нам не притаманне. Поєднання різноманітних форм в єдину систему космічного Розуму відкриває перед людством нові можливості пізнання реальності. Ключем 
до такого об'єднання є взаємна толерантність, взаємна сумісність. Час зрозуміти, що саме толерантність, здатність розвинути її в собі стосовно іншого, сумісність 3 іншим $\epsilon$ вищим проявом Розуму, завдання якого полягає не тільки в тому, щоб зрозуміти Реальність і прояви сутності матерії, а й знайти своє місце в цій багатоманітності, органічно вписатись у неї, при цьому не порушуючи, а, навпаки, зміцнюючи iï сумісність.

Таким чином, соціальна безпека створення ШІ пов'язана з виробленням взаємної толерантності й переконаності у взаємній потребі. Знову ж таки слід акцентувати: виробленню перелічених умов має передувати встановлення (вироблення) толерантності всередині людського суспільства, оскільки без цього жодного взаєморозуміння між штучним інтелектом і людством досягнути не вдасться.

Природа мудра. Зараз не йдеться про існування чи неіснування якогось всесвітнього розуму, але не можна не констатувати, що Природа, створюючи свої закони розвитку, потурбувалася і про те, що така грізна зброя, як ШІ, не має бути надана суспільству із соціальним «вивихом» (навіть якщо цей «вивих»- залишки тоталітаризму). Це й зрозуміло: якщо таке суспільство дістане у своє розпорядження ШІ, то це буде рівносильне самознищенню цього суспільства.

Тільки ставши сумісним всередині себе, ставши внутрішньо толерантним, людство зрозуміє, яким чином треба створювати ШІ, аби він усвідомив себе як складову і невід’ємну частину Всезагального, куди входить і цивілізація гомо сапієнса.

У процесі закладання інформації в мозок штучного інтелекту насамперед треба використовувати принцип сумісності великих інформаційних масивів, поки ШІ сам (незалежно від людини) почне всотувати в себе інформацію, створюючи власні канали її одержання. Таким чином, мова може йти про гуманізацію ШІ і закладення в нього принципів моральності за допомогою інформаційних масивів. У майбутньому, коли Ш почне розвиватися самостійно, інформацію, що суперечить цим принципам моральності, він відкидатиме таку, що вносить несумісність в інформаційні масиви. Вони мають стати жорсткою програмою роботи ШІ. У цьому разі увімкнуться механізми реактивності, котрі блокуватимуть найменші спроби ШІ діяти всупереч консервативній жорсткій програмі моральності.

Найбільшу небезпеку для людства становить варіант створення ШІ в рамках окремої держави. Держава, якій би вдалося здійснити такий проект, дістала б глобальну науково-технічну перевагу над іншими, причому без усякої надії на те, що ця перевага коли-небудь зникне й інші держави зрівняються в своєму розвиткові з нею. Такий варіант імовірний, якщо на той час, коли науково-технічна думка визріє для створення ШІ, світ залишиться політично й економічно роз'єднаним. Якщо до цього в усьому світі не встановиться нове політичне мислення про світ без насильства $\mathrm{i}$ ще сильними будуть ідеї побудови власного благополуччя завдяки іншим, то такий варіант створення ШІ може стати реальністю.

Однак парадокс у тому, що й нація, яка першою створить ШІ у такому варіанті, також неминуче програє. ШІ створюється в обстановці строгої секретності. Правляча еліта, в розпорядження якої потрапляє ШІ, дістає небувалі можливості для утвердження необмеженої влади, що неминуче призведе до абсолютного тоталітаризму й цілковитої соціальної деградації. Історія свідчить, що рівень зовнішнього насильства пропорційний рівневі внутрішнього і навпаки. Тобто народ, який ступив 
на шлях насильства над іншими народами, неминуче стане об’єктом такого ж жорсткого насильства з боку своєї правлячої кліки.

ШІ, як і будь-яке нове відкриття, містить у собі і добро, і зло. Ми звикли до того, що, мовляв, усе залежить від того, у чиїх руках опиниться ШІ. Ці руки спочатку можуть бути найчистішими. Однак, одержавши в своє розпорядження надпотужні інтелектуальні засоби, власники «чистих рук» можуть морально деградувати (а це більш ніж ймовірно, оскільки влада, а надто безконтрольна, розбещує і ставить людину поза мораллю).

Аналізуючи соціальні наслідки інтелектуалізації інформаційних технологій, вчені відзначають їхні як позитивні так і негативні сторони. Відтак були сформулювані певні принципи, яких мають дотримуватись людина і робот аби зменшити ризики комп’ютеризації. У 60-х роках минулого століття американський вчений-хімік і водночас письменник-фантаст Айзек Азімов навіть сформулював такі правила:

- комп’ютер або робот не повинен заподіяти шкоди людині;

- комп’ютер або робот має виконувати накази людини, якщо це не суперечить першому принципу;

- комп’ютер або робот повинен прагнути до самозбереження, якщо це не суперечить першим двом принципам.

Однією з останніх сходинок на шляху до створення штучного інтелекту стала нейромережа - комп'ютерна система, яка відтворює роботу мозку людини, використовуючи ті ж принципи і механізми. Головна відмінність від існуючих комп’ютерних систем - здатність до самостійного навчання.

Об’єднавши квантовий комп'ютер з нейромережею, можна буде вести мову про те, що до створення штучного інтелекту залишиться один крок. Деякі футурологи переконані, що тільки-но штучний розум буде створений, він докладе усіх зусиль, щоб не розкрити себе.

Так чи інакше, але слід пам'ятати, що для людства сучасні комп’ютерні технології можуть бути і корисними, і шкідливими. Залежно від того, в чиїх руках перебувають і якими мотивами керуються їх власни-ки/розробники.

Незважаючи на велику небезпеку, яка таїться у створенні ШІ, він таки буде створений. Це закономірний наслідок історичного процесу розвитку людства. Інша річ, яку мету ставитимуть творці ШІ чи на благо суспільства, чи традиційну - випередити інших у розвитку, встановити панування над світом. Такий шлях, як уже мовилось, веде до всезагального краху. Залишається один - створення Ш силами людства. Це єдино правильне рішення. Але така можливість появиться тоді, коли земляни пройдуть стадію політичної інтеграції. Без такої інтеграції ШІ може перетворитися у засіб насильства. Спершу - насильство одного народу чи держави над іншими, а згодом - насильство ШІ над усім людством.

Подальша доля людства залежить від того, чи розв'яже воно проблему створення штучного інтелекту. І якщо розв'яже, то все залежатиме від того, як розвиватимуться його стосунки зі штучним інтелектом. Будь-які відхилення від ідентичності (людство - Ш) можуть поставити низку нерозв'язних завдань з вкрай небезпечними для цивілізації наслідками.

Упродовж своєї літературної творчості до теми штучного інтелекту неодноразово звертався Станіслав Лем: «Діалоги про кібернетику», «Сума технологій», «Фантастика і футурологія». Приміром, у «Сумі технологій» письменник розглядає три 
альтернативні варіанти, які можуть виникнути в результаті взаємин між Ш і людиною: штучний інтелект ніколи не перевершить людський розум; якщо це й станеться, то людина зможе зберегти контроль над ШІ; людина неспроможна осягнути ШІ і поставити його під свій контроль. Разом з тим письменник був схильний трактувати iii (проблему) і як «експериментальну філософію».

1973 року варшавське видавництво «Czytelnik» випустило у світ знаменитий есей Станіслава Лема «Голем XIV». Це навіть не фантастика, а скоріш фантастична містифікація, своєрідна пародія на «штучний інтелект». Але. Станіслав Лем сам відзначає, що «питання «співіснуання» двох розумів - людського і «нелюдського», біологічного і штучно створеного інтелекту є однією з головних проблем майбутнього». Власне цій проблемі й був присвячений «Голем XIV».

За два дсятиліття перед появою «Голем XIV» у науковому журналі Mind (1950р.) була надрукована знаменита стаття Алана Тьюринга «Чи може машина мислити?» Написана з гумором та іронією публікація містила одну з найоригінальніших і глибоких ідей, висловлених у минулому столітті - автор описав процедуру («гра в імітацію»), за допомогою якої можна буде визначити момент, коли машина зрівняється з людиною в сенсі розумності. Цей «тест Тьюринга» став стандартним теоретичним тестом на «інтелектуальність машини». Тест-завдання припускає, що рівень інтелектуальності співрозмовника визначає його вміння вести діалог.

Критичні завдання, які раз у раз постають перед людством, вже давно перевищують його інтелектуальні можливості у розв'язанні найрізноманітніших соціальних (i не лише) проблем, котрі створюють дедалі більші загрози для виживання гомо сапієнса. Давні міркування Станіслава Лема і Алана Тьюринга стосовно взаємин людини і ШІ нині стали більш ніж актуальними, оскільки будь-яке наукове відкриття і втілення його в реальність у вигляді пристроїв містить в собі нові соціальні проблеми,

Так, знаменитий англійський фізик-теоретик Стівен Хокінг звертав увагу на потенційну загрозу штучного інтелекту для людства, якщо воно не знайде способу уникнути пов'язаних із цим ризиків [10].

Про небезпеку штучного інтелекту висловлюється й Ілон Маск (Elon Musk), американський мільярдер та бізнесмен, засновник SpaceX i Tesla: «Facebook, Google, Amazon, Apple - всі вони вже знають про вас дуже багато. Штучний інтелект, що буде створений в середині цих компаній, отримає велику владу над людьми. А концентрація влади в одних руках завжди породжує величезні ризики. Лише декілька людей в Google працюють над створенням штучного інтелекту, без будь-якого спостереження ззовні - так бути не повинно» [5].

Наразі журналістам, які успішно трудяться в царині публіцистики, аналітики, або є професійними нарисовцями, авторами аргументованих критичних публікацій, конкуренція зі штучним інтелектом не загрожує. Бо навіть найрозумніший робот не $\epsilon$ соціальною істотою, відтак не спроможний на рівні людських емоцій, різноманітних психологічних чинників, притаманних гомо сапієнсу, належним чином оцінити, зрозуміти й відтворити різноманітні явища реальності, в якій перебуває людина.

Разом з тим на тенденції, пов'язані з використанням Ш у мас-медіях, журналісти мають зважати. Йдеться про підвищення загальноосвітнього рівня працівників періодичних видань, глибокого опанування ними спеціальних знань у сфері конкретних наук. 


\section{REFERENCES}

1. Винер Н. Кибернетика и общество / Н. Винер. - М.,1958.

2. Глибовець М. М. Штучний інтелект: підруч. для студ. вищих навч. закладів / М. М. Глибовець, О. В. Олецький. - К. : - Вид. дім «КМ Академія», 2002. - 366 с.

3. Куцай Я. Роботи й журналісти - друзі чи вороги? - Доступно $3:$ https://ms.detector. media/web/online media/roboti yzhurnalisti druzi chi vorogi/ - 3.11 .2016

4. Поспелов Д. А. Фантазия или наука: На пути к искусственному интеллекту / Д. А. Поспелов. - М. : Наука, 1982. - 224 с.

5. Скарбик П. Штучний інтелект: загроза для людства чи помічник? - Доступно 3 : https://itechua.com/technologies/23095 - 21.04.2018

6. Философский словарь / под ред. И. Т. Фролова. - М. : Политиздат, 1981. -445 с.

7. Эндрю А. Искусственный интеллект / А. Эндрю. - М.: Мир, 1985. - 264 с.

8. Яблонська Н. Штучний інтелект та мас-медіа: виклики для підготовки журналістів / Н. Яблнська // Вісник Львівського університету. Серія Журналістика. 2017. - Випуск 42. - С. 95-101.

9. Keohane Joe. What News-Writing Bots Mean for the Future of Journalism. - Доступно $3:$ https://www.wired.com/2017/02/robots-wrote-this-story/ - 16.02.2017.

10. Доступно 3 : https://www.independent.co.uk/news/science/stephen-hawkingtranscendence-looks-at-the-implications-of-artificial-intelligence-but-are-wetaking-9313474.html -1.05 .2014 . 


\title{
ARTIFICIAL-INTELLIGENCE (AI) IN EPOCH OF THE NEW MEDIA
}

\author{
Oleh Romanchuk \\ Ivan Franko National University of Lviv, \\ Generala Chuprynky Str., 49, 79044, Lviv, Ukraine \\ e-mail: universum.magazine@gmail.com
}

The article analyzes the problem of the creation of the artificial-ntelligence (AI) that is very important for the informational society nowadays. Besides the article analyzes the unpredictable social consequences that may arise due to it.

It should be clearly understood that the humanity, which will create the artificial intelligence, will become a qualitatively new system that no longer will be understood and taken in isolation from the artificial intelligence - its further fate will depend on the compatibility of two systems: a common democratic, humanistic system and in a fact an AI-system. This should be taken into account before the creation of the artificial intelligence and must be laid in the process of its development.

We can talk about the humanizing the AI and laying in it the principles of the morality with the help of information arrays. In the future, when AI will begin to develop on its own, it will reject the information that contradicts these principles of the morality as imposing incompatibility in the information arrays.

The greatest danger to mankind is the creation of an AI within the framework of an individual state. A state that would succeed in doing such a project would receive a global scientific and technological advantage over others, and without any hope that this advantage will ever disappear and other states equalize in their development with it.

Despite the great danger that lies behind the creation of the AI, it will be created. This is a logical consequence of the historical development process of the humanity. Another thing that the creators of the AI will put forward: whether for the benefit of the society, or to outsmart others in development, to establish domination over the world. This path, as already mentioned, leads to the general crash. One path remains - the creation of the AI by the forces of the whole humanity.

This is the only right decision. But such an opportunity will appear when the earthlings will go through the stage of the political integration. Without it, the AI can become a means of violence. At first, the violence of one people or state over others, and then - the violence against the whole of the mankind.

According to the inventor and businessman, co-founder of Apple Stephen Wozniak (Stephen Gary Wozniak) there is the potential threat to mankind, associated with the development of the artificial intelligence. Grasping the creativity of the thinking of people, it will represent the force that will be necessary to struggle with. The threat of an uncontrolled development of the artificial intelligence has already been declared by the founder of Microsoft Bill Gates and by the owner, general manager and Chief Engineer of SpaceX Ilon Mask. They are convinced that the machines should be restricted and they shouldn't receive the full freedom for the development.

Key words: information, humanity, communication, information society, Internet resources, computer, communication technologies. 